\title{
Diversity of dinoflagellate assemblages in coastal temperate and offshore tropical waters of Australia
}

\author{
Tahnee Manning ${ }^{1 *} \mathbb{D}$, Arjun Venkatesh Thilagaraj ${ }^{1}$, Dmitri Mouradov² $\mathbb{D}$, Richard Piola ${ }^{3} \mathbb{D}$, Clare Grandison ${ }^{3} \mathbb{D}$, \\ Matthew Gordon ${ }^{3} \mathbb{B}$, Jeff Shimeta ${ }^{1} \mathbb{C}$ and Aidyn Mouradov ${ }^{1}[$
}

\begin{abstract}
Background: Dinoflagellates are a ubiquitous and ecologically important component of marine phytoplankton communities, with particularly notable species including those associated with harmful algal blooms (HABs) and those that bioluminesce. High-throughput sequencing offers a novel approach compared to traditional microscopy for determining species assemblages and distributions of dinoflagellates, which are poorly known especially in Australian waters.
\end{abstract}

Results: We assessed the composition of dinoflagellate assemblages in two Australian locations: coastal temperate Port Phillip Bay and offshore tropical waters of Davies Reef (Great Barrier Reef). These locations differ in certain environmental parameters reflecting latitude as well as possible anthropogenic influences. Molecular taxonomic assessment revealed more species than traditional microscopy, and it showed statistically significant differences in dinoflagellate assemblages between locations. Bioluminescent species and known associates of HABs were present at both sites. Dinoflagellates in both areas were mainly represented by the order Gymnodiniales (66\%— $82 \%$ of total sequence reads). In the warm waters of Davies Reef, Gymnodiniales were equally represented by the two superclades, Gymnodiniales sensu stricto (33\%) and Gyrodinium (34\%). In contrast, in cooler waters of Port Phillip Bay, Gymnodiniales was mainly represented by Gyrodinium (82\%). In both locations, bioluminescent dinoflagellates represented up to $0.24 \%$ of the total sequence reads, with Protoperidinium the most abundant genus. HAB-related species, mainly represented by Gyrodinium, were more abundant in Port Phillip Bay (up to 47\%) than at Davies Reef (28\%), potentially reflecting anthropogenic influence from highly populated and industrial areas surrounding the bay. The entire assemblage of dinoflagellates, as well as the subsets of $\mathrm{HAB}$ and bioluminescent species, were strongly correlated with water quality parameters $\left(R^{2}=0.56-0.92\right)$. Significant predictors differed between the subsets: HAB assemblages were explained by salinity, temperature, dissolved oxygen, and total dissolved solids; whereas, bioluminescent assemblages were explained only by salinity and dissolved oxygen, and had greater variability.

Conclusion: High-throughput sequencing and genotyping revealed greater diversity of dinoflagellate assemblages than previously known in both subtropical and temperate Australian waters. Significant correlations of assemblage structure with environmental variables suggest the potential for explaining the distribution and composition of both HAB species and bioluminescent species.

Keywords: Bioluminescence, Dinoflagellates, eDNA, Genotyping, Harmful algal bloom, High throughput sequencing

\footnotetext{
*Correspondence: tahnee.manning@rmit.edu.au

1 School of Science, RMIT University, Melbourne, VIC, Australia

Full list of author information is available at the end of the article
} original author(s) and the source, provide a link to the Creative Commons licence, and indicate if changes were made. The images or other third party material in this article are included in the article's Creative Commons licence, unless indicated otherwise in a credit line to the material. If material is not included in the article's Creative Commons licence and your intended use is not permitted by statutory regulation or exceeds the permitted use, you will need to obtain permission directly from the copyright holder. To view a copy of this licence, visit http://creativecommons.org/licenses/by/4.0/. The Creative Commons Public Domain Dedication waiver (http://creativeco mmons.org/publicdomain/zero/1.0/) applies to the data made available in this article, unless otherwise stated in a credit line to the data. 


\section{Background}

Dinoflagellates are single-celled protists ubiquitously found in freshwater and marine environments where they occupy many ecological niches. They play significant roles from primary producers through to detritus feeders. Dinoflagellates belong to the class Dinophyceae, which consists of 117 genera including about 4000 freeliving species, plus 500 species with parasitic or mutualist symbiotic lifestyles representing essential symbionts of reef-building corals [1]. Living under diverse environmental conditions, dinoflagellates have developed high complexity in behaviour, nutritional modes (photoautotrophic, heterotrophic, and mixotrophic) and broad morphological diversity, ranging from $5 \mu \mathrm{m}$ to $2 \mathrm{~mm}$.

Dinoflagellate species are known to be a major component of harmful algal blooms (HABs) with a set of physical and chemical effects causing a significant hazard to ecosystems, fisheries, and animal and human health [2]. Physical effects can lead to depletion of oxygen in the water and an increase in viscosity due to the excretion of mucilage. Chemical consequences include the secretion of toxins, that can trigger cell necrosis, affect cell wall penetrability, and suppress the digestive system of other marine organisms as well as potentially humans via either direct exposure or consumption, for example, affected shellfish [3]. HABs are naturally occurring global phenomena but can be triggered by anthropogenic activities, including shipping, eutrophication, and global warming.

There are HAB forming species that also exhibit bioluminescence such as Noctiluca scintillans, although not all bioluminescent dinoflagellates are considered HABs. Sixty-eight dinoflagellate species have evolved bioluminescence, the function of which is still not entirely clear [4]. Bioluminescence is a result of the biochemical process of interaction between a luciferase protein and its substrate, a luciferin, in the presence of a luciferin-binding protein [5]. One of the most widely accepted hypotheses proposes that luminescence increases the survival of dinoflagellates, acting as a "burglar alarm" [6]. The role of bioluminescence as a defence against zooplankton grazers was shown by increased bioluminescence of Lingulodinium polyedra in response to amides produced by their copepod grazers [7]. As a result of bioluminescence, dinoflagellates can successfully persist within marine phytoplankton communities dominated by the similarly sized competitors, diatoms and green algae. However, the existence of non-bioluminescent $N$. scintillans blooms in the northeast Pacific coast of USA, associated with mutation of the luciferase $(l c f)$ gene, disarms this species against their predators [8]. The ecological significance of this phenomenon and a long term existence or disappearing of this mutant will give more information about the importance of bioluminescence as a defence mechanism against predators. Changes in intensity of bioluminescence can be used as a sensitive indicator for the distribution of planktonic biomass in response to physical and chemical changes in surface waters [9], and may offer the possibility of predicting $\mathrm{HAB}$ events in known bloom forming localities [10].

In recent years, omics technologies, such as genomics, transcriptomics, proteomics, and metabolomics, have been extensively applied to study marine dinoflagellates, uncovering essential molecular pathways, such as in toxin biosynthesis, symbiosis, lipid biosynthesis, and HAB formations [11, 12]. Application of molecular techniques to the taxonomy of dinoflagellates such as highthroughput sequencing (HTS) genotyping has led not only to advanced methods for identification of these species but also provides a new tool for understanding their evolutionary complexity and diversity as well as their roles in marine ecological networks [13-18].

Regions targeted for assessment of dinoflagellate diversity include $l c f$ [19], the nuclear ribosomal internal transcribed spacer region (ITS2) $[15,17,20]$, cytochrome $c$ oxidase $1(\mathrm{COI})$ [21], heat shock protein (HSP90) [22], $28 \mathrm{~S}$ rRNA and $18 \mathrm{~S}$ rRNA [13, 23-30]. $18 \mathrm{~S}$ rRNA and $28 \mathrm{~S}$ rRNA have proven highly popular for assessing the diversity of many marine microorganisms [13, 24-26, 28-31]. Recently, the DinoREF dinoflagellate database, has been developed based on V4 regions of $18 \mathrm{~S}$ rRNA sequences [32]. Originally, this database was used to assess the diversity and seasonal changes of dinoflagellates in the Gulf of Naples [27].

The east Australian coastline ranges from the tropical waters of the Great Barrier Reef and Coral Sea to the temperate waters of the Tasman Sea, with water movement driven north to south via the East Australian Current. Because of climate change, many marine species are shifting to higher latitudes $[12,33]$. This has led to changes in the diversity of marine populations in these locations, and has triggered extensive study linking changes in planktonic communities to changes in physical, biological and chemical oceanographic conditions [3, 13-17, 34-37].

Davies Reef (DR) is part of the Great Barrier Reef system within the sub-tropic zone in the Coral Sea, approximately $70 \mathrm{~km}$ from shore [38, 39] (Fig. 1). In contrast, Port Phillip Bay (PPB) is located $2000 \mathrm{~km}$ south within the temperate zone, bordered by Melbourne, the capital city of Victoria, that accommodates 4.96 million people (Fig. 1). There are busy ports, with over 2500 commercial vessels visiting port of Melbourne in 2018-2019 [40] as well as industrial areas contained within the region. As a result, PPB is subject to both direct and indirect anthropogenic influence such as nutrient runoff and industrial pollution [41] that can lead 


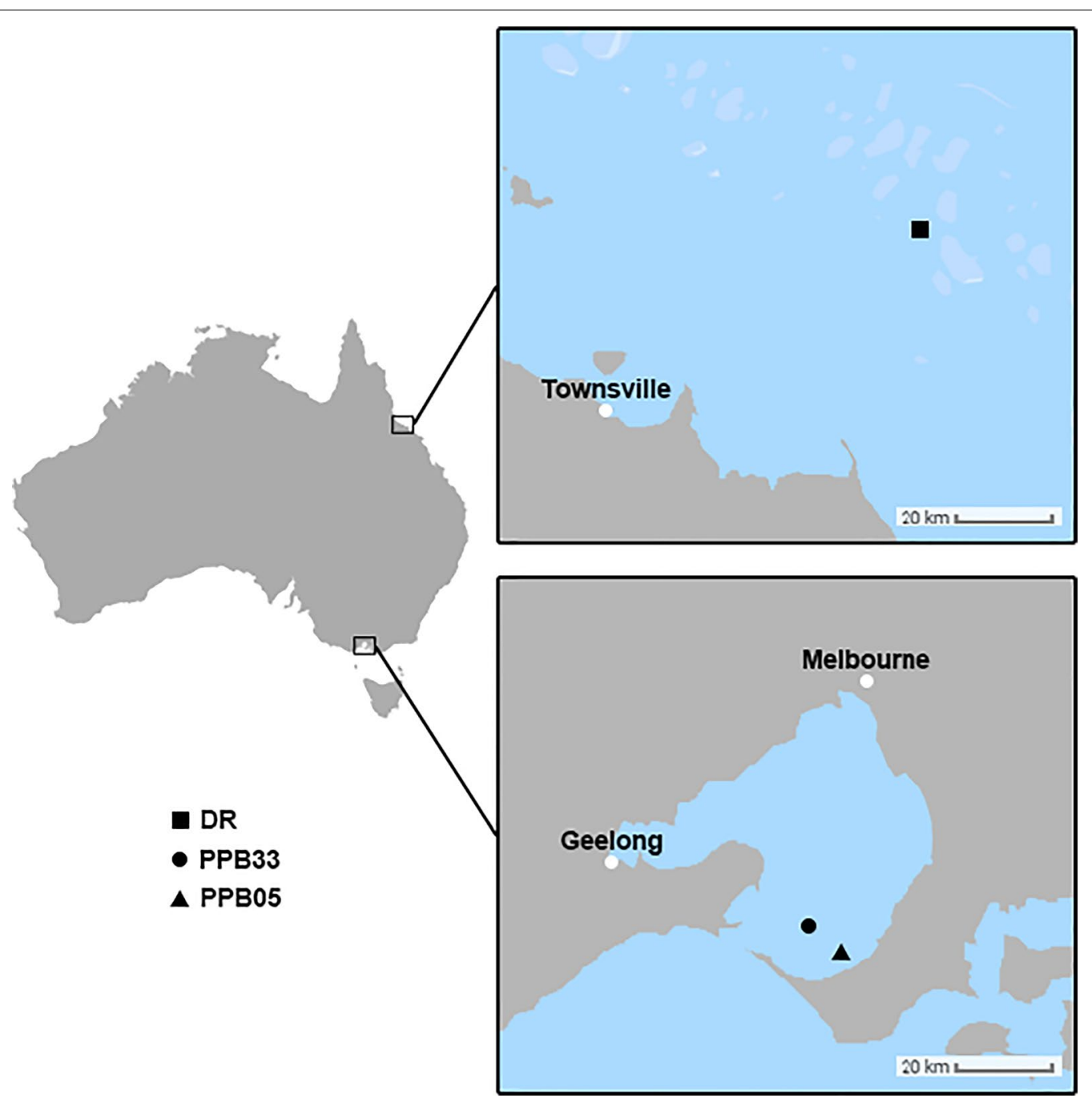

Fig. 1 Locations of study sites, Davies Reef (DR), Queensland, and Port Phillip Bay (PPB), Victoria, Australia. Maps created using Adobe Photoshop, version 21.2.0 (https://www.adobe.com/au/products/photoshop.html)

to the formation of HABs. There is no significant upwelling in the region.

In this study, we assessed the diversity and composition of dinoflagellate assemblages in two different Australian ecosystems: offshore sub-tropical waters at DR and the southern coastal temperate PPB. Taxonomic identification of dinoflagellate diversity was assessed using conventional light microscopy as well as by application of HTS of 18S rRNA amplicons of DNA extracted from environmental samples (eDNA). Correlations between dinoflagellate assemblage structure and environmental factors were found.

\section{Results}

Taxonomic identification of dinoflagellates

Samples were collected from two different Australian locations: offshore tropical waters of Davies Reef, and temperate coastal waters located close to Melbourne city in Port Phillip Bay, Victoria, during June of 2018 (Austral winter) (Fig. 1). Conventional, microscopy based taxonomic identification of the main planktonic representatives (limited to diatoms and dinoflagellates) identified from samples collected at the PPB and DR sites are shown in Additional file 1: Tables S1 and S2. Other taxonomic groups, such as Chrysophytes, Prymnesiophytes, 
Cryptophytes, Prasinophytes, Euglenophyta, and Cyanoprokaryota, were represented in much smaller numbers and are not shown in these tables. Dinoflagellates collected in offshore tropical waters of DR (water temperature $24{ }^{\circ} \mathrm{C}$ ) were mainly represented by Gyrodinium spp. (up to $1.0 \times 10^{3}$ cells $\mathrm{ml}^{-1}$ ), Gymnodinium spp. (up to $6.0 \times 10^{3}$ cells $\mathrm{ml}^{-1}$ ), and Heterocapsa spp. (up to $1.0 \times 10^{4}$ cells $\mathrm{ml}^{-1}$ ), which were found in all analysed samples. The same species were also dominant in cooler, coastal temperate waters of $\mathrm{PPB}$ (water temperature $14{ }^{\circ} \mathrm{C}$ ). Luminescent dinoflagellates in PPB were mainly represented by Noctiluca scintillans (up to $1.5 \times 10^{2}$ cells $\mathrm{ml}^{-1}$ ), with bioluminescence visible at night at the collection areas.

For molecular taxonomy, $18 \mathrm{~S}$ rRNA amplicons (63,619-389,041 per sample) of eDNA collected in DR and PPB were matched against the DinoREF database, revealing 4,331 ribotypes based on $98 \%$ sequence similarity. The identified dinoflagellates across both DR (409 species and a further 45 dentified to genus only) and PPB (404 species and a further 44 identified to genus only) were represented by 8 orders, 23 superclades, 40 families and 150 genera, based on taxonomy reviewed in [32] (Additional file 1: Tables S3, S4, and S5). For the graphical representation of the most abundant superclades, genera, and individual species identified in both locations, an abundance value of $\geq 1 \%$ of sequence reads was used as a threshold. DR samples contained representatives of eleven superclades, composing $97 \%$ of the total sequence reads (Fig. 2a). Superclade Gymnodiniales sensu stricto (one of the largest dinoflagellate clades containing 16 genera) and Gyrodinium (superclade represented by a single genus, Gyrodinium) comprised $34 \%$ and $32 \%$ of sequence reads, respectively. Nine other

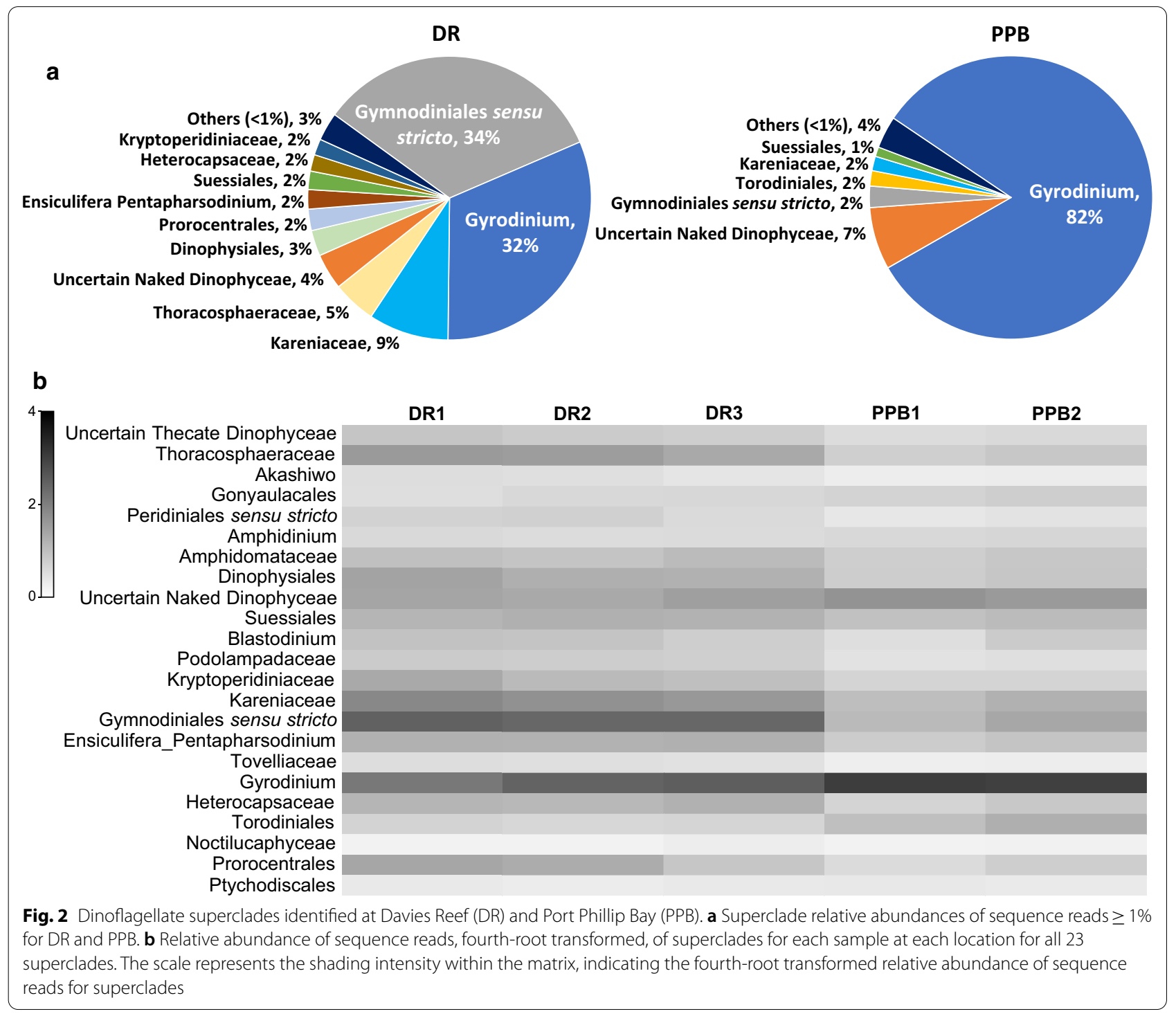


superclades showed $\geq 1 \%$ of sequence reads (Additional file 1: Tables S4 and S5). The same threshold applied to PPB samples showed that $96 \%$ of the total assemblage consisted of just six superclades, with Gyrodinium comprising $82 \%$ of the total sequence reads. Gymnodiniales sensu stricto represented just $2 \%$ of the sequence reads. The shade plot (Fig. 2b) displays all twenty-three superclades' relative abundances, fourth-root transformed to capture both highly represented and rarely represented species, for samples at each location. The overall profiles across samples for PPB indicated the dominance of the genus Gyrodinium. Similarly, for DR samples, the dominance of two superclades, Gymnodiniales sensu stricto and Gyrodinium, can be observed across all samples (Fig. 2b). The graphic representation of these two superclades identified in both locations (with an abundance value of $\geq 1 \%$ of sequence reads) is shown in Fig. 3 and Additional file 1: Table S5. In DR, Gymnodiniales sensu stricto was represented by forty-four species, from which just twelve species showed abundance $\geq 1 \%$ of sequence reads. The genus Gyrodinium was represented by seven species, from which six showed abundance $\geq 1 \%$ : G. spirale (12\%), G. rubrum (8\%), G. gutrula (5\%), G. dominans (4\%), G. heterogrammum (2\%) and G. helveticum (1\%). In PPB, Gyrodinium was comprised of five species with abundance $\geq 1 \%$ : G. spirale (29\%), G. gutrula (18\%), G. dominans (16\%), G. rubrum (15\%) and G. heterogrammum (4\%).

Identified species were categorised as belonging to the HAB-related and/or bioluminescent species groups (Additional file 1: Table S6). Only a small percentage of

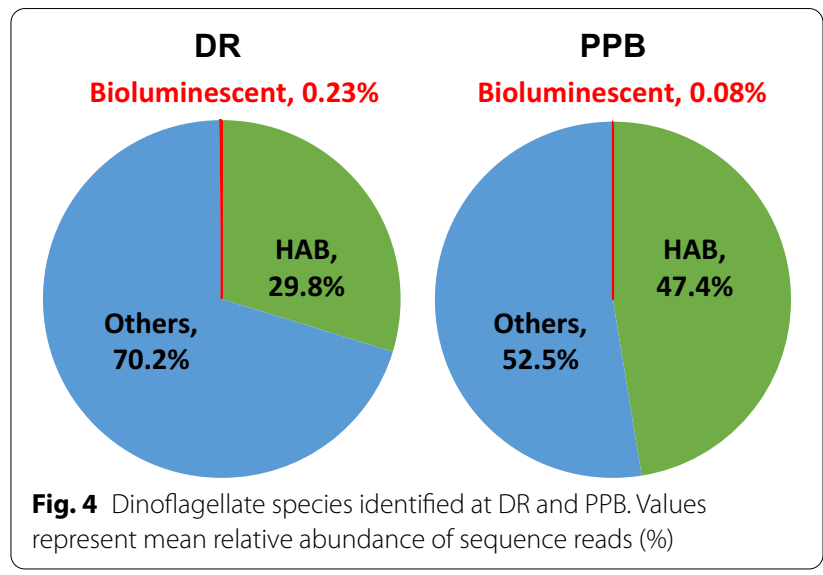

identified species were bioluminescent $(0.23 \%$ and $0.08 \%$ for DR and $\mathrm{PPB}$, respectively), but a larger number were HAB-related (29.8\% and $47.4 \%$ of total assemblages for DR and PPB, respectively) (Fig. 4). Eleven of the HABrelated species belong to the family of bioluminescent dinoflagellates, including five Alexandrium spp., two Gonyaulax and Pyrodinium spp. as well as Lingulodinium polyedra and Noctiluca scintillans (Additional file 1; Table S6).

\section{Bioluminescent dinoflagellates}

A list of bioluminescent dinoflagellate species and the relative abundances of sequence reads for each location is shown in Table 1. In both locations, Protoperidinium was the most abundant genus, being represented by 11

\begin{tabular}{|c|c|c|c|c|c|c|}
\hline & $\mathbf{a}$ & & b & & C & \\
\hline 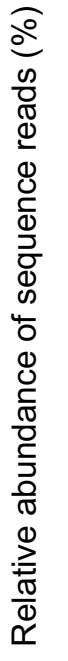 & 10 & $\begin{array}{l}\text { Others (<1\%), } 2 \% \\
\text { Gymnodinium catenatum, 1\% } \\
\text { Gymnoxanthella radiolariae, } 1 \% \\
\text { Gymnodinium litoralis, 1\% } \\
\text { Proterythropsis sp., } 1 \% \\
\text { Lepidodinium viride, 1.1\% } \\
\text { Gymnodinium sp., 1.4\% } \\
\text { Gyrodiniellum shiwhaense, } 1.9 \% \\
\text { Lepidodinium chlorophorum, 1.9\% } \\
\text { Gymnodinium aureolum, } 3 \% \\
\text { Nematodinium sp., } 4 \% \\
\text { Paragymnodinium shiwhaense, } 5 \% \\
\text { Warnowia sp., } 10 \%\end{array}$ & 0 & $\begin{array}{l}\text { G. helveticum, } 1 \% \\
\text { G. heterogrammum, } \\
2 \% \\
\text { G. dominans, } 4 \%\end{array}$ & $\begin{array}{l}40 \\
30 \\
20 \\
10 \\
0\end{array}$ & $\begin{array}{l}\text { G. dominans, } 16 \% \\
\text { G. gutrula, } 18 \% \\
\text { G. spirale, } 29 \%\end{array}$ \\
\hline
\end{tabular}


Table 1 Relative abundance of sequence reads (\%) of bioluminescent dinoflagellate species

\begin{tabular}{|c|c|c|c|}
\hline $\mathrm{DR}$ & $\%$ & PPB & $\%$ \\
\hline Polykrikos kofoidii & 0.10241 & Polykrikos kofoidii & 0.03014 \\
\hline Protoperidinium pellucidum & 0.04454 & Protoperidinium pallidum & 0.01365 \\
\hline Polykrikos schwartzii & 0.02687 & Alexandrium fundyense Group I & 0.00733 \\
\hline Protoperidinium pallidum & 0.01386 & Pyrodinium bahamense var. compressum & 0.00689 \\
\hline Alexandrium fundyense Group I & 0.01271 & Protoperidinium punctulatum & 0.00313 \\
\hline Pyrodinium bahamense var. compressum & 0.00410 & Alexandrium affine & 0.00290 \\
\hline Gonyaulax spinifera & 0.00365 & Noctiluca scintillans & 0.00253 \\
\hline Noctiluca scintillans & 0.00307 & Fragilidium sp. & 0.00219 \\
\hline Protoperidinium punctulatum & 0.00299 & Protoperidinium conicum & 0.00188 \\
\hline Protoperidinium conicum & 0.00227 & Polykrikos schwartzii & 0.00154 \\
\hline Alexandrium affine & 0.00197 & Tripos furca & 0.00126 \\
\hline Fragilidium sp. & 0.00135 & Lingulodinium polyedra & 0.00094 \\
\hline Pyrodinium bahamense var. bahamense & 0.00125 & Pyrocystis lunula & 0.00089 \\
\hline Alexandrium ostenfeldii & 0.00118 & Ceratocorys horrida & 0.00088 \\
\hline Pyrocystis lunula & 0.00116 & Alexandrium monilatum & 0.00085 \\
\hline Lingulodinium polyedra & 0.00108 & Alexandrium ostenfeldii & 0.00084 \\
\hline Tripos furca & 0.00103 & Alexandrium tamarense Group III & 0.00071 \\
\hline Ceratocorys horrida & 0.00087 & Pyrodinium bahamense var. bahamense & 0.00069 \\
\hline Protoperidinium excentricum & 0.00087 & Protoperidinium excentricum & 0.00057 \\
\hline Alexandrium tamarense Group III & 0.00080 & Protoperidinium pellucidum & 0.00051 \\
\hline Alexandrium monilatum & 0.00076 & Gonyaulax spinifera & 0.00043 \\
\hline Protoperidinium divergens & 0.00055 & Protoperidinium divergens & 0.00031 \\
\hline Gonyaulax polygramma & 0.00055 & Protoperidinium leonis & 0.00021 \\
\hline Pyrocystis sp. & 0.00029 & Gonyaulax polygramma & 0.00020 \\
\hline Protoperidinium leonis & 0.00028 & Protoperidinium crassipes & 0.00009 \\
\hline Pyrocystis noctiluca & 0.00026 & Protoperidinium claudicans & 0.00008 \\
\hline Tripos fusus & 0.00025 & Pyrocystis sp. & 0.00007 \\
\hline Pyrophacus steinii & 0.00017 & Pyrophacus steinii & 0.00006 \\
\hline Protoperidinium crassipes & 0.00014 & Protoperidinium depressum & 0.00006 \\
\hline Protoperidinium claudicans & 0.00010 & Tripos horridus & 0.00005 \\
\hline Protoperidinium depressum & 0.00010 & Protoperidinium pentagonum & 0.00004 \\
\hline Protoperidinium pentagonum & 0.00009 & Tripos fusus & 0.00004 \\
\hline Tripos horridus & 0.00001 & Pyrocystis noctiluca & 0.00003 \\
\hline Total: & 0.23156 & & 0.08197 \\
\hline
\end{tabular}

$D R$ Davies Reef, $P P B$ Port Phillip Bay

species, with $P$. pellucidum, the most abundant in DR $(0.04 \%)$ and $P$. pallidum in PPB (0.01\%). Alexandrium, Tripos and Pyrocystis were represented by 5, 3 and 3 species, respectively, in both locations. Gonyaulax, Polykrikos and Pyrodinium were represented by 2 species. Polykrikos kofoidii was the most representative bioluminescent dinoflagellate species identified in both locations, with concentrations over threefold higher in DR $(0.10 \%)$ than in PPB (0.03\%).

\section{HAB-related dinoflagellates}

HAB-related dinoflagellates identified in both locations were represented by 26 genera, which included 92 and 90 species comprising $28.2 \%$ and $47.2 \%$ of all sequence reads, for DR and $\mathrm{PPB}$, respectively (Additional file 1: Tables S6 and S7). HAB-related genera with an abundance $\geq 1 \%$ of sequence reads are shown in Fig. 5 . At DR, Gyrodinium members were among the most abundant (16\%), with a significantly lower representation of other genera, such as Karlodinium (4.2\%), Gymnodinium (2.05\%), Karenia (1.9\%), and Phalacroma (2.0\%). Heterocapsa, Protoceratium, and the total number of the 


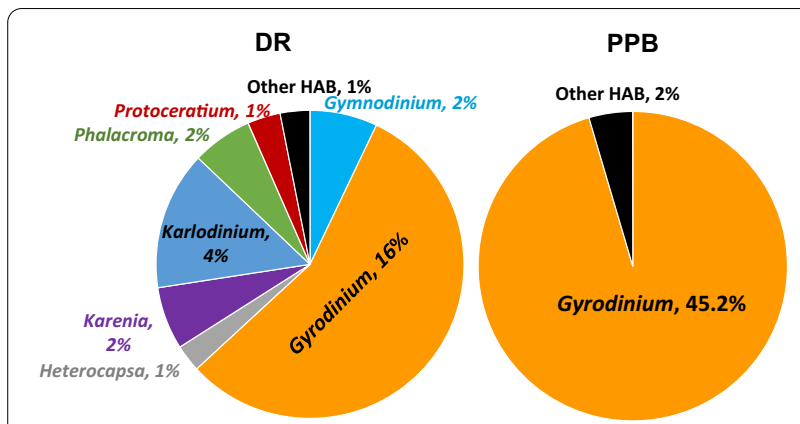

Fig. 5 HAB-related genera and species at Davies Reef (a) and Port Phillip Bay (b). A threshold of $\geq 1 \%$ relative abundance of sequence reads was applied

remaining $\mathrm{HAB}$ representatives counted as $1 \%$. These genera were represented by different numbers of species, with the most abundant, Gyrodinium, including Gyrodinium spirale (12.1\%) and Gyrodinium dominans (4.0\%) (Additional file 1: Tables S6 and S7). However, the least abundant was Prorocentrum, containing 11 species. Alexandrium, a common and abundant member of most $\mathrm{HAB}$ communities, included 17 species in the DR location (only $0.05 \%$ ). The HAB-related dinoflagellate species in PPB were mainly represented by two Gyrodinium species: Gyrodinium spirale (29\%) and Gyrodinium dominans (16\%). The contribution of other HAB-related genera, represented by 88 species, was just $2 \%$ of sequence reads (Fig. 4, Additional file 1: Tables S6 and S7).

\section{Assemblage patterns and correlations with environmental variables}

Non-metric multidimensional scaling (nMDS) results indicated clear separation between samples based on location, with all samples at each location tightly grouped
(Fig. 6a). Principle coordinate analysis (PCO) indicated a strong correlation between the overall assemblage structures and the measured environmental variables optical dissolved oxygen (ODO), salinity, TDS, chlorophyll, $\mathrm{pH}$, and temperature), with replicates for each sample site grouped and clear separation between samples based on location (Fig. 6b). The analysis of similarity (ANOSIM) comparing sequence abundances between locations resulted in $R=1, P=0.001$, indicating 'perfect' separation of sequence abundance based on location. It was determined by similarity percentages species contributions (SIMPER) that the average dissimilarity between the assemblages at the two locations was $24.01 \%$ (Table 2). Over 140 species contributed to the variation, with the top 5 contributors including Warnowia sp., Paragymodinium shiwahaense, and Gyrodinium helveticum, summarised in Table 2.

nMDS results indicated that although there was separation for both assemblage subsets based on location, there was higher within-site variation for the bioluminescent subset compared to the HAB subset (Fig. 7). Nonetheless, both subsets differed significantly between locations, with ANOSIM $R=0.945(P=0.001)$ and $\mathrm{R}=1(P=0.001)$ for the bioluminescent and $\mathrm{HAB}$ subsets, respectively. SIMPER results further supported higher within-site variability for the bioluminescent subset, with the average dissimilarity within DR being $12.35 \%$ for bioluminescent compared to $8.14 \%$ for $\mathrm{HAB}$, and within PPB being $17.38 \%$ for bioluminescent compared to $8.99 \%$ for $\mathrm{HAB}$ (Table 2). SIMPER results also showed that the average dissimilarity between locations was $22.88 \%$ for the bioluminescent subset and $25.99 \%$ for the HAB subset, with 18 and 29 species contributing to the dissimilarity between locations, respectively. The top 5 contributors to the dissimilarity for each subset are summarised in Table 2.
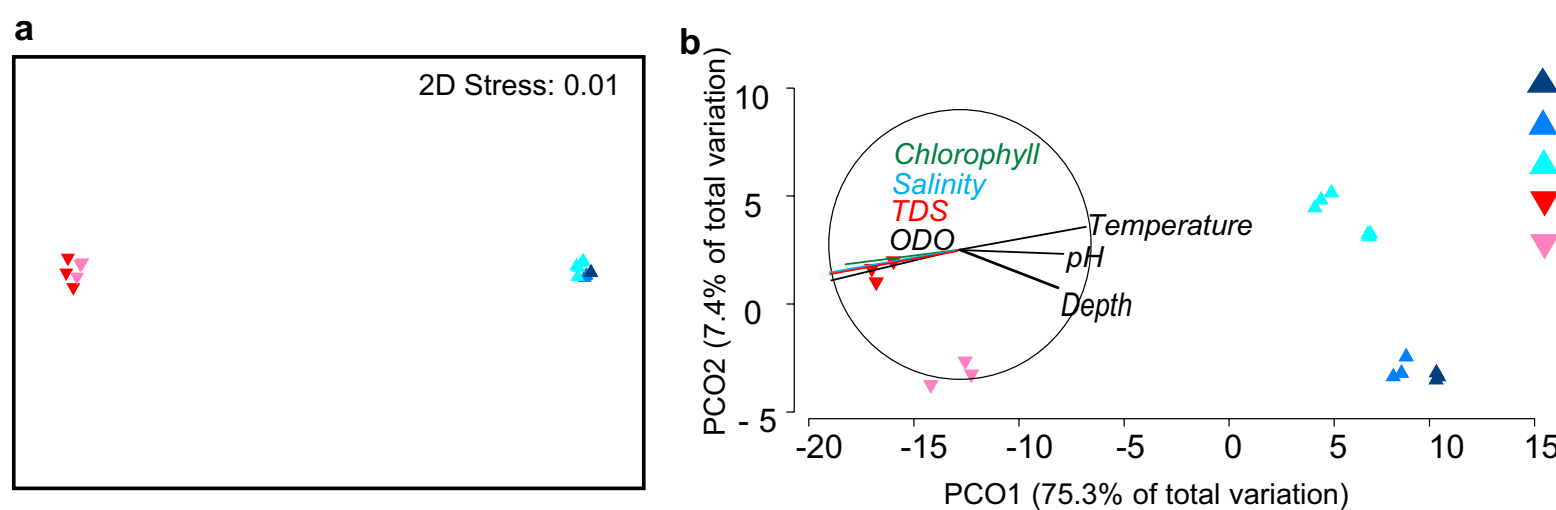

Fig. 6 Diversity of the Davies Reef (DR) and Port Phillip Bay (PPB) sample assemblages. Explored by a nMDS and b PCO based on Bray-Curtis dissimilarity matrices. Environmental variables displayed in vector overlay are dissolved oxygen (ODO), salinity, total dissolved solids (TDS), and chlorophyll a on left side of vector, and temperature, $\mathrm{pH}$ and depth on right side of vector. 
Table 2 Dissimilarity within and between the two locations determined by SIMPER for the whole assemblage, and subsets bioluminescent and HAB species. The top 5 contributors to between-site variation are listed, with the percentage contributed in parentheses

\begin{tabular}{|c|c|c|c|c|c|c|}
\hline & Whole assemblages & & Bioluminescent subset & & HAB subset & \\
\hline $\begin{array}{l}\text { Average dissimilarity } \\
\text { between sites (\%) }\end{array}$ & 24.01 & & 22.88 & & 24.24 & \\
\hline Number contributors & 147 & & 18 & & 30 & \\
\hline \multirow[t]{5}{*}{ Top 5 contributor(s) (\%) } & Warnowiasp. & $(1.61)$ & Lingulodinium polyedra & (8.58) & Karlodinium veneficum & $(4.92)$ \\
\hline & Paragymodinium shiwahaense & $(1.27)$ & Protoperindinium pellucidum & (7.33) & Gymodinium sp. & (3.49) \\
\hline & Nematodinium sp. & $(1.09)$ & Pyrocytis /unula & $(4.81)$ & Phalacroma capa & $(3.34)$ \\
\hline & Protoerythropsis sp. & $(1.00)$ & Polykrikos schwartzii & $(4.75)$ & Phalacroma mitra & (3.33) \\
\hline & Gyrodinium helveticum & $(0.96)$ & Alexandrium monilatum & $(4.66)$ & Prorocentrum rhathymum & $(3.24)$ \\
\hline \multicolumn{7}{|c|}{ Average dissimilarity of replicates within sites (\%) } \\
\hline \multicolumn{2}{|c|}{ Davies Reef } & 8.46 & & 12.35 & & 8.14 \\
\hline \multicolumn{2}{|l|}{ Port Phillip Bay } & 11.00 & & 17.38 & & 8.99 \\
\hline
\end{tabular}

a

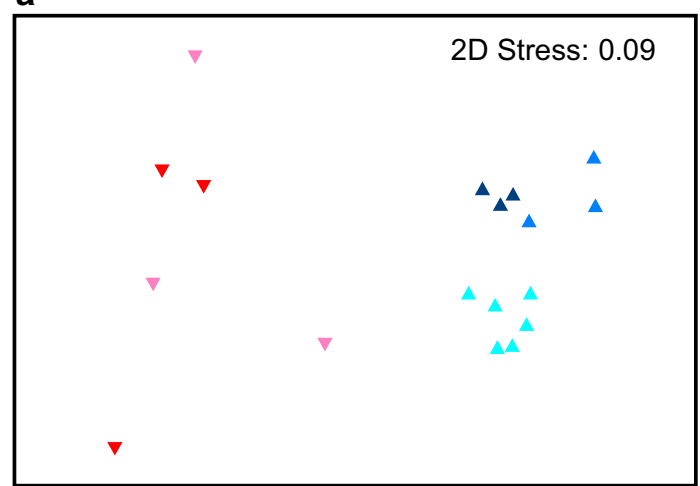

b

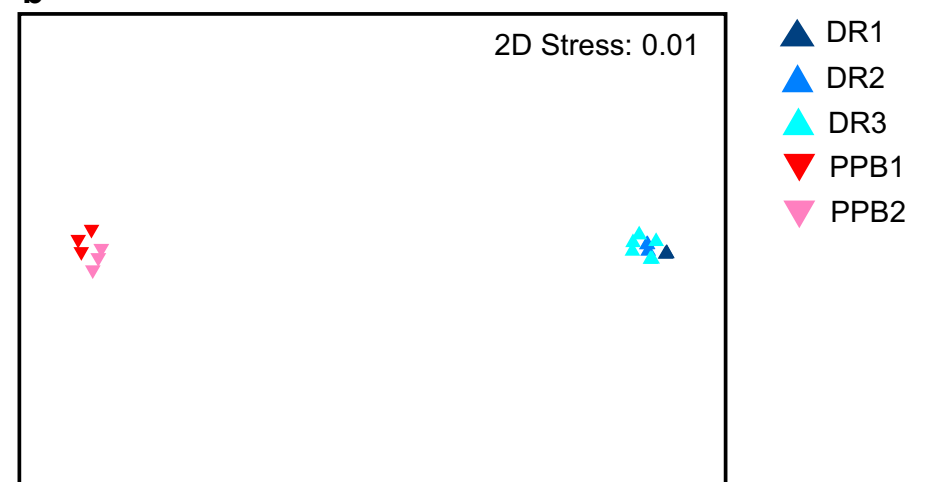

Fig. 7 Diversity of the Davies Reef (DR) and Port Phillip Bay (PPB) subset assemblages. Explored by nMDS based on Bray-Curtis dissimilarity matrices. a Bioluminescent subset nMDS. b HAB subset nMDS

Distance-based linear models (DistLM) determined that $88 \%$ of the total variation in the entire assemblages at the two locations was best explained by three environmental variables: salinity, temperature, and ODO (Table 3). In contrast, for the bioluminescent subset, only the two variables salinity and ODO significantly explained the assemblage differences (accounting for $56 \%$ of the variation); whereas, for the HAB subset, the four variables salinity, temperature, ODO and depth were significant and explained $92 \%$ of the variation (Table 3 ). Importantly, 1) salinity was the strongest explanatory factor for both subsets of assemblages, and 2) temperature and depth only explained HAB assemblages, not bioluminescent assemblages.

\section{Discussion}

Our aim was to assess the diversity and composition of dinoflagellate assemblages at two different Australian locations using both conventional microscopy and eDNA sampling with HTS genotyping. It was expected that both methods would detect similar genera, with HTS potentially detecting broader diversity than conventional methods. Although widely reported for other regions such as Europe and North America, the use of HTS for assessing diversity and composition of dinoflagellates in Australian waters is less common. HTS is typically utilised for detection of one species rather than for an overall assessment of dinoflagellates assemblages. We have demonstrated the feasibility of utilising eDNA sampling with HTS genotyping for assessment of dinoflagellate diversity across different locations. 
Table 3 Distance-based linear models (DistLM) for determination of environmental variables that explain assemblage variation. Variables included in the sequential analysis were Chlorophyll a, ODO, salinity, TDS, pH, temperature and depth, with only terms that remained in the best fit model presented

\begin{tabular}{lccc}
\hline Variable & Pseudo-F & P-value & \% variation \\
\hline Whole assemblage & $\left(R^{2}=0.88 ; \mathrm{AlCC}=63.47\right)$ & \\
Salinity & 42.97 & 0.001 & 72.87 \\
Temperature & 7.30 & 0.001 & 8.88 \\
ODO & 7.02 & 0.001 & 6.09 \\
Bioluminescent subset $\left(\mathrm{R}^{2}=0.56 ; \mathrm{AlCC}=84.77\right)$ & \\
Salinity & 12.84 & 0.001 & 44.51 \\
ODO & 4.09 & 0.001 & 11.89 \\
HAB subset $\left(\mathrm{R}^{2}=0.91 ; \mathrm{AlCC}=60.59\right)$ & & \\
Salinity & 55.92 & 0.001 & 77.75 \\
Temperature & 6.06 & 0.001 & 6.40 \\
ODO & 6.24 & 0.002 & 4.89 \\
Depth & 4.02 & 0.002 & 2.59 \\
\hline
\end{tabular}

$O D O$ optical dissolved oxygen, TDS total dissolved solids

Microscopy-based taxonomic analysis of environmental samples found that the two locations had low numbers of dinoflagellates compared to diatoms and other flagellates (Additional file 1: Tables S1 and S2). The dinoflagellate diversity was restricted to 17 genera. HTS confirmed the presence of these genera but identified much greater diversity-around 150 genera in total. However, the results here for the two most abundant dinoflagellate genera (Gyrodinium and Gymnodinium) concurred with the molecular results. Traditional methods using light microscopy can be prone to underestimating the diversity of dinoflagellate species; particularly for athecate (i.e. lacking thecal plates or unarmoured) dinoflagellates, identification is often only possible to the order or genus level due to fragile structural components being damaged during collection (e.g. netting) and fixation [42]. Due to the level of underestimation, inferences derived from traditional methods may lead to mischaracterisation of the evolutionary history and ecology of the organisms at these marine locations. Comparisons between traditional surveys of marine organisms and more recent molecular surveys utilising eDNA coupled with HTS have shown that although the identified taxa may vary, the differences arise due to advantages and disadvantages of each method and, overall, the methods are complementary $[43,44]$.

The eukaryotic markers used here revealed a high level of diversity within the total assemblages at both locations. The application of HTS showed the ability to detect even trace levels of dinoflagellates amongst the other taxa contained in these planktonic communities [15]. The use of HTS has shown that protists, and dinoflagellates in particular, have high levels of diversity within marine communities [21, 27].

Tropical waters of DR were represented by 11 superclades from which Gymnodiniales sensu stricto, and Gyrodinium showed $64 \%$ relative abundance of sequence reads. In contrast, the cold waters of PPB were dominated a single genus, Gyrodinium, with abundances of $82 \%$ of sequence reads. Typically prevalent in coastal waters, Gyrodinium species are globally ubiquitous, unarmoured (athecate) heterotrophs [1, 45]. Like all dinoflagellates, Gyrodinium spp. exhibit slow growth rates compared to other phytoplankton (e.g. ciliates, diatoms) [46].

A very low percentage of the dinoflagellate assemblage was identified as being bioluminescent species, especially considering sampling was undertaken either during or following bioluminescent events (Table 1, Fig. 4). However, the results here indicate that $N$. scintillans was present in very low numbers at both sites, with the most abundant bioluminescent species being Polykrikos kofoi$d i i$, a heterotrophic, unarmoured, free-living bioluminescent dinoflagellate [47] (Table 1). There could have been other sources of bioluminescence in the water from other organisms such as bacteria that were not sequenced by the $18 \mathrm{~S}$ rRNA primers used.

The list of bioluminescent and HAB-related species was developed by comparison of the DinoREF database to the wider literature and is by no means exhaustive. It must be noted that these two 'subsets' are not mutually exclusive, with eleven species belonging to both HAB and bioluminescent subsets (Table S6). Further, several 18S rRNA sequences of bioluminescent dinoflagellate species detected in previous studies of South-Eastern Australian waters are missing from the DinoREF database. These included two species for which we added reference sequences (Noctiluca scintillans and Pyrocytis noctiluca) and one for which there was not a sequence available (Pyrocystis fusiformis). Thus, in order to assess the bioluminescent species present in dinoflagellate assemblages in Australian waters, further development of the DinoREF database by the addition of more reference species is required. For better identification of bioluminescent species, $18 \mathrm{~S}$ rRNA-based data could be complemented by genotyping based on variations in $l c f$. Both general and species-specific $l c f$ gene primers are available [19, 48-51]. However, non-bioluminescent strains of Alexandrium tamarense, Ceratocorys horrida and Noctiluca scintillans were demonstrated to contain the $l c f$ gene $[8,50]$, indicating that although useful, further methods to confirm bioluminescence are needed. Transcriptomics alongside proteomics revealed that $P$. lunula contains the gene for, and actively expresses, luciferase binding 
protein, not previously observed for this species [52]. Extending the use of 'omics' technologies to other bioluminescent dinoflagellates will help reveal the relationships between bioluminescent taxa and the expression and/or activity of bioluminescence.

HAB-related dinoflagellates can be divided into five groups: 1) high-biomass blooming, non-toxic species that directly or indirectly kill marine species via deoxygenation of water or other physical effects upon the water column; 2) food-poisoning toxin producers causing either neurological or gastrointestinal symptoms in humans; 3) those not harmful to humans, but harmful to marine organisms via mechanical effects such as gill damage, or haemolytic compound secretion; 4) toxin producers harmful to humans, particularly in aerosols; and 5) those listed as not toxic to humans but shown to produce toxins, thus potentially dangerous [1, 4, 53-55]. Using these definitions, almost half the total assemblage from PPB was identified as HAB-related, being dominated by Gyrodinium spirale and G. dominans (Fig. 5). These two species were also dominant within the HAB subset at DR, although not to the same extent as at PPB. Due to the potential economic and health impacts of HABs, DinoREF was screened for sequences of potentially toxic dinoflagellates $[2,27,32,56]$. PPB is subject to high levels of direct and indirect anthropogenic influences, which could explain the up-to 1.6 fold higher representation of identified HAB-related taxa.

The representation of HAB-related genera did not correspond to their respective species diversity. The most abundant genus, Gyrodinium (16-42\%), was represented just by 2 species from the possible 7 described in the DinoREF database. In contrast, one of the least abundant genera, Alexandrium (0.05-0.1\%), was comprised of 17 species from the possible 23 contained in the DinoREF database, however all 23 Alexandrium species were identified in the whole assemblages (Additional file 1: Table S4 and S5). Of the species identified here, 11 are previously reported from Australian waters [16, 57, 58]. There are also many reports of Alexandrium catenella, Group IV, in Australian waters, a known HAB associated with paralytic shellfish poisoning; however, this species is not contained in the DinoREF database. Still, there were 13 Alexandrium species detected that were not previously known to be present in Australian marine waters, including $A$. andersonii, A. cohorticula, A. hiranoi, $A$. insuetum, A. leei, A. mediterraneum, Group II, $A$. monilatum, $A$. pohangense, A. satoanum, A. tamarense Group III, A. tamiyavanichii, A tamutum and A. taylorii. Another HAB species not previously reported in Australian waters but detected at low relative abundances here is Karenia brevis [58]. These novel findings clearly highlight the usefulness of the ability to be able to detect rare and less abundant taxa utilising eDNA sampling and HTS genotyping.

The significant variation of assemblage structures between locations (Figs. 6, 7; Table 2) and their strong correlations with environmental variables (Table 3) suggest that species presence and relative abundance of sequence reads are constrained by temperature and salinity [59]. Interestingly, while the dinoflagellate assemblage as a whole was explained to $88 \%$ by the measured environmental parameters, the explanatory power diverged when separating out the bioluminescent and HABrelated subsets: $\mathrm{HAB}$ assemblages were explained to $92 \%$, whereas bioluminescent assemblages were explained only to $56 \%$. This result suggests that the distribution and relative abundances of $\mathrm{HAB}$ species are more strongly influenced by environmental factors than are bioluminescent species. However, the distribution and abundance of bioluminescent species maybe affected by other parameters that were not measured such as the presence of other prey and/or predator species. The result is also consistent with the higher within-site variability observed for the bioluminescent assemblage compared to the $\mathrm{HAB}$ assemblage regardless of location (Fig. 7; Table 2). However, the ecological mechanisms producing this pattern are unknown, and elucidation would require further temporal surveys. The stronger environmental influence on HAB assemblages is also reflected by their correlation with four parameters (salinity, temperature, ODO, and depth), whereas bioluminescent assemblages correlated with only two (Table 3). The first three parameters explaining $\mathrm{HAB}$ assemblages (salinity, temperature and ODO) are all influenced by anthropogenic activity, consistent with studies indicating that HABs are triggered by human impacts (reviewed by [2]). It is important to note that nutrients considered important stressors for dinoflagellate growth, such as nitrogen and phosphate, were not measured here. Regardless, our finding that $\mathrm{HAB}$ species were more predominant at PPB than at DR is also consistent with the extensive anthropogenic impacts documented in PPB [41]. In contrast, neither temperature nor depth were significant explanatory factors for bioluminescent assemblages, and indeed the ecological and environmental constraints on the distribution of bioluminescent species are poorly known in comparison, although recent studies have begun to elucidate some of these relationships, for example, Noctiluca scintillans tolerates a wide range of salinity and temperatures [35].

The species that differed most between locations (top five including Warnowia sp., Paragymodinium shiwahaense, and Gyrodinium helveticum shown in Table 2) are the ones most likely to be strongly impacted by environmental variation since those that contributed less to dissimilarity are essentially distributed more evenly. 
However, the differences in distribution may reflect differences more broadly in biogeographic ranges that are related to other factors not measured here. Furthermore, the data here are from a single time point, whereas any phenological differences in population dynamics among species could cause assemblage differences to fluctuate seasonally. As PPB is a temperate latitude embayment, it experiences stronger spring plankton blooms than DR within the tropics, thus the samples collected during Austral winter likely represent a seasonal low point at PPB. A temporal study of assemblage structure with HTS genotyping and measurements of environmental factors expanded to include nutrients such as nitrogen and phosphate could provide more insight into the constraints on both $\mathrm{HAB}$ and bioluminescent assemblages.

\section{Conclusions}

- Application of HTS in genotyping enables the detection of rare and less abundant taxa compared to traditional methods. Further, all taxa identified using microscopic techniques were detected using HTS genotyping. However, HTS genotyping detected approximately ninefold higher numbers of taxa compared to traditional methods and expanded upon the previously described diversity for these two locations.

- Comprehensive microscopy-based and molecular taxonomic assessments of two different Australian ecosystems revealed a greater diversity of dinoflagellates in the warm waters of DR (with eleven superclades, from which Gymnodiniales sensu stricto and Gyrodinium comprised 33\% and 34\% of sequence reads, respectively), compared to the cooler waters of PPB that were dominated by the superclade Gyrodinium (82\%).

- Up to 1.5-fold higher concentrations of HAB-related species were identified in PPB compared to DR, possibly reflecting the greater anthropogenic influences in this area.

- Bioluminescent species were represented by only up to $0.23 \%$ of total sequence reads.

\section{Methods}

\section{Sample collection}

DR (Great Barrier Reef, Queensland; GPS: -18.8284 147.6354) samples were collected over a 4-day period: day 1 (three replicate samples from site DR1), day 2 (three replicate samples from site DR2), and day 4 (six replicate samples from site DR3). PPB samples were collected on a single night from two sites (three replicate samples from each site, PPB1 and PPB2) (GPS: -38.2759
144.8304 for station PPB1 and -38.3274 144.9034 for station PPB2). Water samples were collected using a $15 \mathrm{~L}$ Niskin bottle at discrete depths within the water column, selected to be within the range of observed bioluminescence. Depths of sampling at DR were $15 \mathrm{~m}$ (DR1) and $10 \mathrm{~m}$ (DR2 \& 3), while all samples at PPB were taken at $8 \mathrm{~m}$. For microscopical identification of species, a $1 \mathrm{~L}$ collection bottle was filled and preserved using a final concentration of $0.1-0.5 \%$ Lugol's iodine solution and stored in a dark, cooled insulated container. Microscopical identification was performed by Microalgal Services, Ormond, Victoria, Australia [60]. For molecular identification of species, samples were prefiltered through a $50 \mu \mathrm{m}$ mesh sieve to remove large organisms and/or debris, then $6-8 \mathrm{~L}$ were filtered through Whatman glass fiber filters $(0.45 \mu \mathrm{m}$ pore size, $47 \mathrm{~mm}$ diameter) under vacuum. All filters were placed in $15 \mathrm{~mL}$ Falcon tubes and stored at $-20{ }^{\circ} \mathrm{C}$, either immediately or transferred to the laboratory on ice in a dark insulated container then frozen, until processed. To obtain a profile of the water column, an EXO1 Multiparameter Sonde (YSI) was used with measurements recorded typically for both down and upcast. Parameters measured included chlorophyll a, conductivity, depth, ODO, redox potential, salinity, phycoerythrin fluorescence (indicating cyanobacteria), TDS, $\mathrm{pH}$, temperature and GPS latitude and longitude.

\section{DNA extraction and sequencing}

DNA was isolated from filters using an optimised CTAB method [61]. Filters were immersed in $500 \mu \mathrm{L}$ of pre-warmed $\left(65^{\circ} \mathrm{C}\right) \mathrm{CTAB}$ isolation buffer $(2 \%$ CTAB (Sigma, Saint Louis, USA), $1.4 \mathrm{M} \mathrm{NaCl}, 100 \mathrm{mM}$ Tris $\mathrm{pH}$ 8.0, $20 \mathrm{mM}$ EDTA PVP, 0.01\% w/v SDS, 0.2\% mercaptoethanol). Samples were vortexed for $5 \mathrm{~min}$, then briefly cooled on ice before the addition of a 1:1 solution of chloroform and isoamyl alcohol (24:1 v/v) (Sigma, Saint Louis, USA). Samples were centrifuged at $\approx 12,000 \mathrm{xg}$ for $10 \mathrm{~min}$ and the supernatant collected and re-extracted twice as described. Samples were cooled on ice for $5 \mathrm{~min}$, then centrifuged at $\approx$ $12,000 \mathrm{xg}$ for $15 \mathrm{~min}$. DNA pellets were washed with $500 \mu \mathrm{L}$ of $70 \%$ ethanol, centrifuged at $\approx 12,000 \times g$ for $6 \mathrm{~min}$, and air-dried. DNA was re-suspended in $50 \mu \mathrm{L}$ of DNase-free water and stored at $4{ }^{\circ} \mathrm{C}$ overnight for the complete dissolution of DNA. The quantity and purity of template DNA was assessed using a Nanodrop spectrophotometer (PicoDrop Ltd, Hinxton, UK). The dinoflagellate $18 \mathrm{~S}$ rRNA gene was amplified utilising primers based on Zhang, Bhattacharya [62]: 18ScomF1 (5'-GCTTGTCTCAAAGATTAAGCCATGC-3') and Dino18SR1 (5'-GAGCCAGATRCDCACCCA-3') using 
$1 \mu \mathrm{L}$ of extracted DNA (100 ng/ $\mu \mathrm{L})$. PCR was undertaken with an initial denaturation at $95{ }^{\circ} \mathrm{C}$ for $3 \mathrm{~min}$, followed by 40 cycles of denaturation at $95^{\circ} \mathrm{C}$ for $35 \mathrm{~s}$, annealing at $53{ }^{\circ} \mathrm{C}$ for $40 \mathrm{~s}$ and extension at $72{ }^{\circ} \mathrm{C}$ for $1 \mathrm{~min}$ with final extension at $72{ }^{\circ} \mathrm{C}$ for $5 \mathrm{~min} .18 \mathrm{~S}$ rDNA amplicons $(\approx 1.75 \mathrm{~kb})$ were sequenced by the Australian Genome Research Facility (www.https://www.agrf. org.au/) using paired-end Illumina sequencing.

\section{Data analyses}

A dinoflagellate (Dinophyceae) $18 \mathrm{~S}$ rRNA reference database was created by downloading DinoREF (Pub med REF PMID: 29603631), containing a non-redundant curated set of 422 species, and adding to it the 18S rRNA sequences of Noctiluca scintillans (GenBank: KR527331.1) and Pyrocystis noctiluca (GenBank: AF022156.1) [63], which were of interest and absent from DinoREF. Raw fastq files were pre-processed using BBDuk [64], removing adaptor and poor quality sequences. The following parameters were used with BBDuk: "ktrim $=\mathrm{r} k=23$ mink $=11$ hdist $=1$ tpe tbo $\mathrm{ftl}=31$ trimq $=15$ ". This included a hard trim of 31 bases to remove adaptor, kmer-trimming, primer (dimer) trimming, as well as quality trimming (to Q15). Pre-processed fastq files were aligned against the $18 \mathrm{~S}$ rRNA reference using Burrows-Wheeler Alignment (bwa mem v0.7.17) tool [65]. Conversion into BAM format and extraction of uniquely mapped reads was carried out using SAMtools [66]. Chimeric and multimapped reads were filtered out via SAMtools with using the "SA" tag and -bq1 command. SAMtools was further used to count reads aligned to each dinoflagellate species.

The DinoREF analysis resulted in an Excel spreadsheet containing the number of sequence reads that aligned to each entry, as well as a taxa file. Excel was used to determine the relative abundance of sequence reads as a percentage, using formula 1 , and generate profiles of the total dinoflagellate assemblage for each location (i.e. average of DR and average of PPB).

Formula 1: $\left(\frac{\text { no of sequnce reads }}{\text { total sample sequence readss }}\right) \times 100 \%$

For environmental data, YSI data were exported to Excel. The relevant environmental data were selected by using the average measurements over a $1 \mathrm{~m}$ range corresponding to the depth of the plankton sample. For example, for plankton samples taken at $10 \mathrm{~m}$, environmental measurements from 9.6 to $10.5 \mathrm{~m}$ were selected and averaged.

Relationships between biological and environmental data were tested with PRIMER and PERMANOVA +. The numbers of sequences were treated as abundances. Status of species as bioluminescent or HAB-related were added as indicators. Environmental variables were chlorophyll a $(\mu \mathrm{g} / \mathrm{L})$, ODO $(\mathrm{mg} / \mathrm{L})$, salinity (psu), TDS (mg/L),
$\mathrm{pH}$, temperature $\left({ }^{\circ} \mathrm{C}\right)$ and depth $(\mathrm{m})$. Environmental data were normalised, and a resemblance matrix based on Euclidean distance was generated. In order to capture both highly represented and rarely represented species, biological data were transformed to the fourth root, and a resemblance matrix based on Bray Curtis similarity was generated. Relationships between biological and environmental data were analysed by nMDS and PCO, with the significance of separation determined by ANOSIM. SIMPER was used to determine the taxa that contributed most to the variation. To determine the environmental variables that explained the relationships, a DistLM with stepwise selection criteria of Akaike Information Criterion (AICc) regression was used, allowing for identification of predictor variables that contributed significantly to the assemblage variation between the two locations. Analyses of the bioluminescent and HAB subsets were undertaken as for the whole assemblages. A taxa file for species, genus, family, and order was included for analyses of taxa within the assemblages. A second taxa file for species and superclade, as determined by Mordret et al. [32], was also included. Biological data were analysed at different taxonomical levels using AGGREGATE function and shade plots.

\section{Supplementary Information}

The online version contains supplementary material available at https://doi. org/10.1186/s12862-021-01745-5.

Additional file 1: Table S1. Taxonomic identification of the main planktonic representatives, diatoms and dinoflagellates at Davies Reef. $X$ denotes species observed in sample during initial microscopic examination but not encountered during cell counting. Table S2. Taxonomic identification of the main planktonic representatives, diatoms and dinoflagellates at Port Phillip Bay. X denotes species observed in sample during initial microscopic examination but not encountered during cell counting. Table S3. Taxonomy and relative abundance of sequence reads (\%) for all sample replicates. DR: Davies Reef; PPB: Port Phillip Bay. Table S4. Mean relative abundance of sequence reads of dinoflagellate superclades, genera and species as defined by Mordret et al. (2018) at Davies Reef (DR) and Port Phillip Bay (PPB). The superclade Noctilucaphyceae was added to reflect the addition of Noctiluca scintillans to the DinoREF database. Table S5. Mean relative abundance of sequence reads (\%) of dinoflagellate species identified at Davies Reef (DR) and Port Phillip Bay (PPB). Table S6. List of bioluminescent and $\mathrm{HAB}$ species identified within the two dinoflagellate assemblages. HAB species are assigned numbers 1-5, based on the typologies as defined by Lassus et al. [1, 4, 53-55]. Table S7. Mean relative abundance of sequence reads (\%) of $\mathrm{HAB}$-related species at Davies Reef (DR) and Port Phillip Bay (PPB).

\section{Abbreviations}

ANOSIM: Analysis of similarity; COI: Cytochrome c oxidase 1; DistLM: Distance based linear models; DR: Davies Reef; HAB: Harmful algal blooms; HTS: High throughput sequencing; ITS2: Nuclear ribosomal internal transcribed spacer region; nMDS: Non-metric multi-dimensional scaling; ODO: Optical dissolved oxygen; PCO: Principle coordinate analysis; PPB: Port Phillip Bay; SIMPER: Similarity percentages-species contributions; TDS: Total dissolved solids. 


\section{Acknowledgements}

The authors are grateful to Maritime Division, Defence Science \& Technology Group (Australia) for initiation and financial support of this project; Ms Lou Montelli involved in collection of samples; Dr Shamila Abeynayake for designing some of the dinoflagellate primers. The authors wish to acknowledge the use of the services and facilities of AGRF.

\section{Authors' contributions}

AM, JS designed and coordinated this project, interpreted data and contributed to writing the manuscript; AVT extracted eDNA and prepared 18S rRNA amplicons; RP involved in collection and biochemical analysis of water samples; TM wrote the manuscript, undertook statistical analysis and interpreted data; DM analysed sequencing data and bioinformatics; CG and MG critically read and interpreted data. All authors were involved in final approval of the version to be published and agreed to be accountable for all aspects of the work. All authors read and approved the final manuscript.

\section{Funding}

The work has been funded by the Defence Science and Technology Organisation Research Agreement-Development of culturing procedures and molecular characterisation methodology for bioluminescent dinoflagellates MyIP: 9346. Contract Code: 32071. Funders contributions to the research were: RP involved in collection and biochemical analysis of water samples; CG and MG critically read the manuscript and interpreted data.

\section{Availability of data and materials}

All data generated or analysed during this study are included in this published article (and its supplementary information files).

\section{Ethics approval and consent to participate}

This study did not use animals. This study complies with the current Australian rules for collection of marine microorganisms.

\section{Consent for publication}

Not applicable.

\section{Competing interests}

The authors declare that they have no conflict of interest.

\section{Author details}

${ }^{1}$ School of Science, RMIT University, Melbourne, VIC, Australia. ${ }^{2}$ Personalised Oncology Division, The Walter and Eliza Hall Institute of Medical Research, Parkville, VIC, Australia. ${ }^{3}$ Maritime Division, Defence Science \& Technology Group, Fishermans Bend, Canberra, VIC, Australia.

\section{Received: 15 September 2020 Accepted: 7 January 2021}

\section{Published online: 15 February 2021}

\section{References}

1. Gómez F. A list of free-living dinoflagellate species in the world's oceans. Acta Bot Croat. 2005:64(1):129-212.

2. Shumway SE, Burkholder JM, Morton SL. Harmful algal blooms : a compendium desk reference. Newark: John Wiley \& Sons, Incorporated; 2018.

3. Hallegraeff GM. Harmful algal blooms in the Australian region. Mar Pollut Bull. 1992:25(5-8):186-90.

4. Marcinko CLJ, Painter SC, Martin AP, Allen JT. A review of the measurement and modelling of dinoflagellate bioluminescence. Prog Oceanogr. 2013;109:117-29.

5. Haddock SHD, Moline MA, Case JF. Bioluminescence in the sea. Annu Rev Mar Sci. 2010;2:443-93.

6. Abrahams MV, Townsend LD. Bioluminescence in dinoflagellates: a test of the burgular alarm hypothesis. Ecology. 1993;74(1):258-60.

7. Prevett A, Lindstrom J, Xu J, Karlson B, Selander E. Grazer-induced bioluminescence gives dinoflagellates a competitive edge. Curr Biol. 2019;29(12):R564-5

8. Valiadi M, de Rond T, Amorim A, Gittins JR, Gubili C, Moore BS, et al. Molecular and biochemical basis for the loss of bioluminescence in the dinoflagellate Noctiluca scintillans along the west coast of the USA. Limnol Oceanogr. 2019;64(6):2709-24.
9. Prairie JC, Sutherland KR, Nickols KJ, Kaltenberg AM. Biophysical interactions in the plankton: a cross-scale review. Limnol Oceanogr: Fluid Environ. 2012;2(1):121-45.

10. Le Tortorec A, Hakanen P, Kremp A, Olsson J, Suikkanen S. Stimulated bioluminescence as an early indicator of bloom development of the toxic dinoflagellate Alexandrium ostenfeldii. J Plankton Res. 2014;36:412-23.

11. Anderson DM, Cembella AD, Hallegraeff GM. Progress in understanding harmful algal blooms: paradigm shifts and new technologies for research, monitoring, and management. Annu Rev Mar Sci. 2012;4(1):143-76.

12. Wells ML, Karlson B, Wulff A, Kudela R, Trick C, Asnaghi V, et al. Future HAB science: Directions and challenges in a changing climate. Harmful Algae. 2020:91:101632.

13. Brown MV, van de Kamp J, Ostrowski M, Seymour JR, Ingleton T, Messer $L F$, et al. Systematic, continental scale temporal monitoring of marine pelagic microbiota by the Australian Marine Microbial Biodiversity Initiative. Sci Data. 2018:5:180130.

14. Farrell $H$, Brett $S$, Ajani P, Murray S. Distribution of the genus Alexandrium (Halim) and paralytic shellfish toxins along the coastline of New South Wales. Australia Mar Pollut Bull. 2013;72(1):133-45.

15. Quigley KM, Davies SW, Kenkel CD, Willis BL, Matz MV, Bay LK. Deepsequencing method for quantifying background abundances of symbiodinium types: exploring the rare symbiodinium biosphere in reef-building corals. PLoS ONE. 2014;9(4):e94297.

16. Sparrow L, Momigliano P, Russ GR, Heimann K. Effects of temperature, salinity and composition of the dinoflagellate assemblage on the growth of Gambierdiscus carpenteri isolated from the Great Barrier Reef. Harmful Algae. 2017;65:52-60.

17. Ziegler M, Stone E, Colman D, Takacs-Vesbach C, Shepherd U. Patterns of Symbiodinium (Dinophyceae) diversity and assemblages among diverse hosts and the coral reef environment of Lizard Island. Australia J Phycol. 2018;54(4):447-60.

18. Zingone A, D'Alelio D, Mazzocchi MG, Montresor M, Sarno D. Time series and beyond: multifaceted plankton research at a marine Mediterranean LTER site. Nat Conserv. 2019;34:273.

19. Baker A, Robbins I, Moline MA, Iglesias-Ridriguez MD. Oligonucleotide primers for the detection of bioluminescent dinoflagellates reveal novel luciferase sequences and information on the molecular evolution of this gene. J Phycol. 2008:44:419-28.

20. Arif C, Daniels C, Bayer T, Banguera-Hinestroza E, Barbrook A, Howe CJ, et al. Assessing Symbiodinium diversity in scleractinian corals via nextgeneration sequencing-based genotyping of the ITS2 rDNA region. Mol Ecol. 2014:23(17):4418-33.

21. Stern RF, Horak A, Andrew RL, Coffroth M-A, Andersen RA, Küpper FC, et al. Environmental barcoding reveals massive dinoflagellate diversity in marine environments. PLOS ONE. 2010. https://doi.org/10.1371/journ al.pone.0013991.

22. Hoppenrath M, Leander BS. Dinoflagellate phylogeny as inferred from heat shock protein 90 and ribosomal gene sequences. PLOS ONE. 2010;5(10):e13220.

23. Balzano S, Abs E, Leterme SC. Protist diversity along a salinity gradient in a coastal lagoon. Aquat Microb Ecol. 2015;74(3):263-77.

24. Comeau AM, Lagunas MG, Scarcella K, Varela DE, Lovejoy CJA. microbiology e. Nitrate consumers in arctic marine eukaryotic communities: comparative diversities of 18S rRNA, 18S rRNA genes, and nitrate reductase genes. Applied Environ Microb. 2019;85(14):e00247-e319.

25. Countway PD, Vigil PD, Schnetzer A, Moorthi SD, Caron DA. Seasonal analysis of protistan community structure and diversity at the USC Microbial Observatory (San Pedro Channel, North Pacific Ocean). Limnol Oceanogr. 2010;55(6):2381-96.

26. Hu SK, Liu Z, Lie AA, Countway PD, Kim DY, Jones AC, et al. Estimating protistan diversity using high-throughput sequencing. J Eukaryot Microbiol. 2015;62(5):688-93.

27. Mordret S. Integrated study of dinoflagellate diversity in the Gulf of Naples [PhD Thesis]: The Open University; 2018.

28. Onda DF, Medrinal E, Comeau AM, Thaler M, Babin M, Lovejoy C. Seasonal and interannual changes in ciliate and dinoflagellate species assemblages in the Arctic Ocean (Amundsen Gulf, Beaufort Sea, Canada). Front Mar Sci. 2017:4:16.

29. Piredda R, Tomasino MP, D’Erchia AM, Manzari C, Pesole G, Montresor M, et al. Diversity and temporal patterns of planktonic protist assemblages 
at a Mediterranean Long Term Ecological Research site. FEMS Microbiol Ecol. 2017. https://doi.org/10.1093/femsec/fiw200.

30. Sze Y, Miranda LN, Sin TM, Huang D. Characterising planktonic dinoflagellate diversity in Singapore using DNA metabarcoding. MBMG. 2018;2:e25136

31. Shang L, Hu Z, Deng Y, Liu Y, Zhai X, Chai Z, et al. Metagenomic sequencing identifies highly diverse assemblages of dinoflagellate cysts in sediments from ships' ballast tanks. Microorganisms. 2019;7(8):250.

32. Mordret S, Piredda R, Vaulot D, Montresor M, Kooistra WHCF, Sarno D. DINOREF: a curated dinoflagellate (Dinophyceae) reference database for the 18S rRNA gene. Mol Ecol Resour. 2018;18(5):974-87.

33. Verma A, Hughes DJ, Harwood DT, Suggett DJ, Ralph PJ, Murray SA. Functional significance of phylogeographic structure in a toxic benthic marine microbial eukaryote over a latitudinal gradient along the East Australian Current. Ecol Evol. 2020;00:1-17.

34. Hallegraeff GM, Davies C. 3.3 Tripos dinoflagellates as indicators of Australian marine bioregions. Australia: Integrated Marine Observing System (IMOS); 2020.

35. Hallegraeff GM, Davies C, Rochester W. 3.6 Range expansion of the red tide dinoflagellate Noctiluca scintillans. Australia: Integrated Marine Observing System (IMOS); 2020.

36. Hallegraeff GM, Steffensen DA, Wetherbee R. Three estuarine Australian dinoflagellates that can produce paralytic shellfish toxins. J Plankton Res. 1988:10(3):533-41.

37. McLeod D, Hallegraeff G, Hosie G, Richardson A. Climate-driven range expansion of the red-tide dinoflagellate Noctiluca scintillans into the Southern Ocean. J Plankton Res. 2012:34:332-7.

38. ABS. Data by Region: Autralian Bureau of Statistics; 2019. https://itt.abs. gov.au/itt/r.jsp?databyregion. Accessed 18 May 2020

39. Huddlestone-Holmes C, Gigan G, Woods G, Ruxton A, Atkinson I, Kininmonth S. Infrastructure for a Sensor Network on Davies Reef, Great Barrier Reef. 3rd International Conference on Intelligent Sensors, Sensor Networks and Information: IEEE; 2007. p. 675-9.

40. PA. Annual Port Statistics from around the nation, 2018-2019: Ports Australia; 2020 https://www.portsaustralia.com.au/resources/trade-stati stics. Accessed 18 May 2020

41. Carnell PE, Keough MJ. Reconstructing historical marine populations reveals major decline of a kelp forest ecosystem in Australia. Estaur Coast. 2019;42(3):765-78.

42. Gómez F. Gymnodinioid Dinoflagellates (Gymnodiniales, Dinophyceae) in the open pacific ocean. Algae. 2007;22(4):273-86.

43. Deagle BE, Clarke LJ, Kitchener JA, Polanowski AM, Davidson AT. Genetic monitoring of open ocean biodiversity: an evaluation of DNA metabarcoding for processing continuous plankton recorder samples. Mol Ecol. 2018;18(3):391-406

44. Kelly RP, Closek CJ, O'Donnell JL, Kralj JE, Shelton AO, Samhouri JF. Genetic and Manual Survey Methods Yield Different and Complementary Views of an Ecosystem. Front Mar Sci. 2017;3:283.

45. Kim JS, Jeong HJ. Feeding by the heterotrophic dinoflagellates Gyrodinium dominans and G. spirale on the red-tide dinoflagellate Prorocentrum minimum. Mar Ecol Prog Ser. 2004;280:85-94.

46. Hansen PJ. Prey size selection, feeding rates and growth dynamics of heterotrophic dinoflagellates with special emphasis on Gyrodinium spirale. Mar Biol. 1992;114(2):327-34.

47. Matsuoka $\mathrm{K}, \mathrm{Cho} \mathrm{H}-\mathrm{J}$, Jacobson DM. Observations of the feeding behavior and growth rates of the heterotrophic dinoflagellate Polykrikos kofoidi (Polykrikaceae, Dinophyceae). Phycologia. 2000;39(1):82-6.

48. Le Tortorec AH, Tahvanainen P, Kremp A, Simis SGH. Diversity of luciferase sequences and bioluminescence production in Baltic Sea Alexandrium ostenfeldii. Euro J Phycol. 2016:51(3):317-27.
49. Liu L, Wilson T, Hastings JW. Molecular evolution of dinoflagellate luciferases, enzymes with three catalytic domains in a single polypeptide. PNAS. 2004;101(47):16555-60

50. Valiadi M, Debora Iglesias-Rodriguez M, Amorim A. Distribution and genetic diversity of the luciferase gene within marine dinoflagellates. J Phycol. 2012;48(3):826-36.

51. Valiadi M, Painter SC, Allen JT, Balch WM, Iglesias-Rodriguez MD. Molecular detection of bioluminescent dinoflagellates in surface waters of the patagonian shelf during early austral summer 2008. PLOS ONE. 2014;9(6):e98849

52. Fajardo C, Amil-Ruiz F, Fuentes-Almagro C, De Donato M, Martinez-Rodriguez G, Escobar-Nino A, et al. An "omic" approach to Pyrocystis lunula: New insights related with this bioluminescent dinoflagellate. Proteomics. 2019;209:103502.

53. AlgaeBase. World-wide electronic publication, [Internet]. National University of Ireland. 2020. https://www.algaebase.org. Accessed 03 Jun 2020

54. Lassus P, Chomerat N, Hess P, Nezan E. Toxic and Harmful Microalgae of the World Ocean. Denmark: International Society for the Study of Harmfu Intergovernmental Oceanographic Commission of UNESCO; 2016.

55. Valiadi M, Iglesias-Rodriguez D. Understanding bioluminescence in dinoflagellates-how far have we come? Microorganisms. 2013;1 (1):3-25.

56. Richmond RH, Tisthammer KH, Spies NP. The effects of anthropogenic stressors on reproduction and recruitment of corals and reef organisms. Front Mar Sci. 2018. https://doi.org/10.3389/fmars.2018.00226.

57. Hallegraeff G, Bolch C, Condie S, Dorantes-Aranda J, Murray S, Quinlan R, et al. Unprecedented Alexandrium blooms in a previously low biotoxin risk area of Tasmania, Australia 2018.

58. Hallegraeff GM, Schweibold L, Jaffrezic E, Rhodes L, MacKenzie L, Hay $B$, et al. Overview of Australian and New Zealand harmful algal species occurrences and their societal impacts in the period to 2018, including a compilation of historic records. Harmful Algae. 2020. https://doi. org/10.1016/j.hal.2020.101848.

59. Fuhrman JA, Steele JA, Hewson I, Schwalbach MS, Brown MV, Green JL, et al. A latitudinal diversity gradient in planktonic marine bacteria. Proc Natl Acad Sci. 2008;105(22):7774-8.

60. Microalgal Services. Phytoplankton monitoring and identification: Bellcurve; 2020. https://microalgal.com.au/. Accessed 30 June 2020.

61. Doyle J. DNA protocols for plants. In: Hewitt GM, Johnston AWB, Young JPW, editors. Molecular techniques in taxonomy. Berlin: Springer; 1991. p. 283-93.

62. Zhang H, Bhattacharya D, Lin S. Phylogeny of dinoflagellates based on mitochondrial cytochrome $b$ and nuclear small subunit rDNA sequence comparisons. J Phycol. 2005;41(2):411-20.

63. Saunders GW, Hill DRA, Sexton JP, Andersen RA. Small-subunit ribosomal RNA sequences from selected dinoflagellates: testing classical evolutionary hypotheses with molecular systematic methods. In: Bhattacharya D, editor. Origins of Algae and their Plastids. Vienna: Springer ; 1997. p. 237-59.

64. Bushnell B. BBMap 2017. https://sourceforge.net/projects/bbmap/. Accessed 3 Dec 2018

65. Li H, Durbin R. Fast and accurate short read alignment with BurrowsWheeler transform. Bioinformatics. 2009;25(14):1754-60.

66. Li H, Handsaker B, Wysoker A, Fennell T, Ruan J, Homer N et al. The sequence alignment/map format and SAMtools. Bioinformatics. 2009:25(16):2078-9.

\section{Publisher's Note}

Springer Nature remains neutral with regard to jurisdictional claims in published maps and institutional affiliations. 